вміст у їх зеленій масі біологічно активних речовин, що володіють антиоксидантною, анаболічною та іншими діями на організм сільськогосподарських тварин в умовах промислового їх використання

\title{
References
}

Baraboj, B. A. (1984). Rastite/'ny’e fenoly' i zdorov'e cheloveka. Moskva: Nauka (in Russian).

Bulanov, Y. B. (1993). Anabolicheskie sredstva. Tver”: Posrednik (in Russian).

Vovk, S. O., \& Pavkovych, S. Y. (2008). Osoblyvosti lipidnoho i zhyrno kyslotnoho zhyvlennia teliat . Ekolohichni, tekhnolohichni ta sotsialno-ekonomichni aspekty efektyvnoho vykorystannia materialno-tekhnichnoi bazy APK, 38-42 (in Ukrainian).

Zinchenko, I. H. (2013). Farmakohnostychne vyvchennia tyfonu. (Master's thesis). Kharkiv (in Ukrainian).

Kulyk, M. F., Zhmud, O. V., \& Obertiukh, Y. V. (1999). Biolohichno aktyvni rechovyny soi - stymuliatory syntezu lipidiv moloka $v$ orhanizmi koriv. Visnyk ahrarnoi nauky, 10, 37-38(in Ukrainian).

Levashova, O. L., Burd, N. B., Hnoievyi, V. I., \& et al. (2002). Priorytetni silskohospodarski kultury - dzherelo biolohichno aktyvnykh rechovyn. Farmatsiia KhKh/ stolittia, 166-16 (in Ukrainian).

Prudnikov, V. H., Lysenko, H. L., \& Vasylieva, Y. O. (2015). Tekhnolohiia vyrobnytstva yalovychyny. Kharkiv: Stil-Izdat.

Tsyhanok, A. V., Drozdov, S. Y., Kutikov, Y. S., \& Hnoievyi, V. I. (1999). Pro efekt synkhronizatsii terminiv prykhodu u pershu statevu okhotu remontnykh svynok za rakhunok vvedennia u ratsion sylosu z amarantu. Naukovotekhnichnyi Biuleten Instytutu zemlerobstva i biolohii tvaryn, 1, 153-154 (in Ukrainian).

Koch, D. W., Ernst, F. C., \& Leonard, N. R. (1987). Lamb performance on extended-season grazing of tyfon. Journal of animal science, $2,1275-1279$

William, N. T. (2002). Anabolic therapy in modern medicine: 2nd ed. North Carolina: McFarland\&Co.

\section{FEATURES OF FORMATION OF INDICATORS OF LIFETIME USE OF COWS OF THE BROWN BREEDS OF THE NORTH-EAST OF UKRAINE}

\author{
Y. I. Sklyarenko \\ Institute of Agriculture of Northern East of NAAS \\ Sad, Sumy district, Sumy region, Ukraine, 42343 \\ E-mail: Sklyrenko9753@ukr.net
}

Recently, scientists have paid great attention to the study of identifying the factors that determine the indicators of lifetime use of cows. This issue is particularly relevant in the context of the widespread use of bull-producers of imported dairy breeds in Ukraine. Among the genetic factors, the father's heredity has a noticeable effect on the duration and effectiveness of the productive use of cows. The aim of the research is to study the effect of genotypic factors on the duration of economic use of brown cows. The studies were conducted in the breeding plant of the State Enterprise "Experimental Farm of the Institute of Agriculture of Northern East of NAAS" of Sumy region for breeding Ukrainian brown dairy breed. A retrospective analysis of the duration and efficiency of lifetime use of cows was carried out using the method of Y.P. Polupan, 2010.

It is established that the conditional kindred of animals of the Swiss breed significantly influenced the majority of indicators characterizing indicators of lifetime use of cows $(\eta 2 x=1,7-15,2 \%$.). Life expectancy was longer in animals with conditional kindred of the Swiss breed from 25.1 to $50 \%$. They are respectively significantly superior to animals with conditional kindred $75,1-87,5 \%$ (for $16 \%, P<0,05$ ), 87,6-93,8\% (for $29 \%$, $P<0,05$ ), $100 \%$ (for $34 \%, P<0,01$ ). Purebred Lebedinian animals also had a high rate of lifetime and its value is significantly dominated by kindred of Swiss breed animals: $87,6-93,8 \%$ (for $36 \%, P<0,01$ ), $100 \%$ (for $46 \%$, $P<0,05)$. Animals of the Lebedinian breed by the number of lactations have an advantage which reliably $(P<0,01-0,05)$ prevailed kindred animals of Swiss breed, respectively: $75,1-87,5$ - for $41 \%, 87,6-93,8 \%$ for $87 \%, 100 \%$ - for $89 \%$. Accordingly, the duration of the lactation period was longer in purebred Lebedinian animals. In terms of lifetime milk yield animals with conditional kindred of Swiss breed had the advantage of $25.1-50.0 \%$ - $24169.5 \mathrm{~kg}$, purebred Lebedinian animals - $23756 \mathrm{~kg}$ and with conditional kindred 50.1$75 \%$ - $22467 \mathrm{~kg}$. Animals with less conditional kindred on improving breed also had an average lifetime productivity more than 20,0 thousand $\mathrm{kg}$ of milk. The lowest average gross yield was observed in animals with a conditional share of the Swiss breed of $100 \%$. Linear affiliation did not have a significant impact on the indicators of lifetime use of cows. The greatest force of influence on the productive longevity of cows had a factor of father origin ( $n 2 x=23,4-26,9 \%)$. The highest life expectancy differed daughters of bulls-producers Bigboy 9973 of Distinkshna 159523 line (4399 days) and Major 543 of Pavena 136140 line (4350 days). The shortest life expectancy was in the daughters of a bullproducer Poliden 3950 of Elegant 148551 line (1432 days). This trend is typical for indicators of the duration of economic use and lactation period. A larger average lifetime milk yield is typical for the daughters of the bull-producer Major 243, which was $33127 \mathrm{~kg}$.

We have studied the influence of purebred Lebedinian and Swiss bulls on the studied parameters. It was found that the daughters of pure-breed Lebedinian bulls had the advantage in the average values of all the studied indicators. Moreover, the difference in the number of lactation and lactation period was significant $(P<0,05)$.

Key words: bull-producer, lifetime productivity, coefficient, lactation, milk yield. 


\title{
ОСОБЛИВОСТІ ФОРМУВАННЯ ПОКАЗНИКІВ ДОВІЧНОГО ВИКОРИСТАННЯ КОРІВ БУРИХ ПОРІД ПІВНІЧНОГО СХОДУ УКРАЇНИ
}

\author{
Ю. І. Скляренко \\ Iнститут сільського господарства Північного Сходу Нацјональної академії аграрних наук України \\ с. Сад, Сумський район, Сумська область, Украйна, 42343 \\ E-mail: Sklvrenko9753@ukr.net
}

\begin{abstract}
Дослідження проведені в племінному заводі Державного підприємства «Дослідне господарство /нституту сільського господарства Північного Сходу НААН» Сумського району з розведення украйнської бурої молочної породи.Ретроспективний аналіз тривалості та ефективності довічного використання корів здійснювали за методикою Ю.П.Полупана, 2010. Встановлений достовірний високовірогідний вплив генотипових фоккторів на показники довічного використання корів. Найбільиу силу впливу на продуктивне довголіття корів мав фрактор походження за батьком $\left(\eta^{2}{ }_{x}=23,4-26,9 \%\right)$. Умовна кровність за швіцькою породою також достовірно впливала на показники довічного використання тварин. Сила впливу на окремі показники знаходилась в межах $\eta^{2} x=1,7-15,2 \%$. Лінійна належність не мала достовірного суттєвого впливу на показники довічного використання тварин.
\end{abstract}

Ключові слова: бугай-плідник, довічна продуктивність, коефіцієнт, лактація, надій.

$\begin{array}{cc}\text { Вступ } & \\ \text { Актуальність } & \text { теми. Вітчизняними }\end{array}$ науковцями приділяється велика увага пошуку шляхів селекції молочної худоби на підвищення тривалості ії використання та довічної продуктивності (Buyuklu, Taranenko, \& Noskova, 2013; Polupan, 2014). Дослідники зазначають, що тривалість використання та довічна продуктивність корів обумовлюється, як генотиповими, так і паратиповими фоккторами (Polupan, 2010; Polupan, 2013). Використання кращуого світового генофонду для створення та покращення вітчизняних порід зумовлює науковців досліджувати їх вплив на показники тривалості господарського використання тварин.

Аналіз останніх досліджень і публікацій. Як зазначає Хмельничий Л.М. (Khmel'nychyi, \& Boyko, 2010; Khmel'nychyi, \& Vechorka, 2016), рентабельність галузі скотарства визначається витратами на вирощування ремонтного молодняку, відтворення стада, на забезпечення технологічних процесів годівлі та доїння корів, і, значною мірою, рівнем продуктивності поголів'я.

Науковці вважають, що тривалість господарського використання корів відноситься до спадкових ознак і тому вона залежить, у першу чергу, від генетичних чинників: породи, методів підбору, кровності за поліпшуючою породою (Khmel'nychyi, \& Boyko, 2010; Chechenihina, 2014).

Результатами багатьох досліджень (Buyuklu, Taranenko, \& Noskova, 2013; Khmel'nychyi, \& Vechorka, 2016) встановлено, що 3 збільшенням частки крові за покращуючою породою у корів молочних порід знижується тривалість господарського використання.

Як зазначають науковці (Buyuklu, Taranenko, \& Noskova, 2013; Polupan, 2014; Khmel'nychyi, \& Boyko, 2010; Sewalem, Miglior, Kistemaker, \& Van Doormaal, 2006; Sewalem, Miglior, Kistemaker, Sullivan, \& Van Doormaal, 2008; Haworth, Tranter, Chuck, Cheng, \& Wathes, 2008; Terawaki, \& Ducrocq, 2009), серед генетичних чинників помітний вплив на показники тривалості та ефективності продуктивного використання корів має спадковість за батьком. Відомо, що в останні десятиріччя для покращення продуктивних якостей вітчизняної молочної худоби використовують плідників голштинської та швіцької порід.
Mema роботи - вивчення впливу генотипових факторів на показники тривалості господарського використання корів бурих порід.

Завдання дослідження: дослідити залежність показників тривалості господарського використання від умовної кровності за швіцькою породою, лінійної належності та походження за батьком. Встановити силу впливу кожного з генотипових факторів на показники тривалості господарського використання.

\section{Матеріал і методи досліджень}

Дослідження проведені на базі племінного господарства 3 розведення української бурої молочної породи. До вибірки залучено інформацію первинного зоотехнічного обліку (Система управління молочним скотарством «Орсек») племінних тварин в Державному підприємстві «Дослідне господарство Інституту сільського господарства Північного Сходу НАAН» Сумського району.

Ретроспективний аналіз тривалості та ефективності довічного використання корів здійснювали за методикою Ю.П. Полупана (Polupan, 2010). Для оцінки тривалості та ефекктивності довічного використання по кожній досліджуваній корові враховували інформацію про дату народження, дату першого отелення, дату вибуття зі стада. По кожній лактації (включно з можливо незакінченою останньою) враховували ії тривалість, надій за всю лактацію. На підставі вищенаведених показників для кожної тварини вирахували тривалість життя, господарського використання і лактування, довічний надій, середній надій на один день життя, на один день господарського використання. Коефіцієнт господарського використання (Кгв) обчислювали (для зручності - 3 вираженням у відсотках) за формулою пропонованою М.С.Пелехатим зі співавторами (10).

Силу впливу $\left(\eta^{2} x\right)$ різних генотипових та паратипових чинників на основні господарськи корисні ознаки вивчали методом однофакторного дисперсійного комплексу через співвідношення факторіальної дисперсії до загальної за методиками Н. А. Плохинского на персональному комп'ютері 3 використанням програмного забезпечення Statistica 6.0

Результати досліджень та їх обговорення 
ВЕТЕРИНАРІЯ, ТЕХНОЛОГІЇ ТВАРИННИЦТВА ТА ПРИРОДОКОРИСТУВАННЯ, 2018 , №2 Науково-практичний журнал Харківської державної зооветеринарної академії

Результати ретроспективного аналізу засвідчили достовірний вплив генотипових факторів на показники тривалості життя, господарського використання та довічної продуктивності корів підконтрольного господарства (табл. 1).
Умовна кровність тварин за швіцькою породою достовірно впливала на більшість показників, які характеризують показники довічного використання корів. Сила впливу за окремими показниками знаходилась в межах 1,7 -15,2\%.

Таблиця 1

Сила впливу генотипових факторів на показники довічного використання корів, $\eta^{2} \times(n=310)$

\begin{tabular}{|c|c|c|c|c|c|}
\hline \multirow[b]{3}{*}{ Показники } & \multicolumn{5}{|c|}{ Генотипові фьактори } \\
\hline & \multicolumn{2}{|c|}{ умовна кровність } & \multirow[b]{2}{*}{$\begin{array}{c}\text { лінійна } \\
\text { належність }\end{array}$} & \multirow[b]{2}{*}{$\begin{array}{c}\text { походження за } \\
\text { батьком }\end{array}$} & \multirow[b]{2}{*}{$\begin{array}{c}\text { умовна } \\
\text { кровність } \\
\text { батька }\end{array}$} \\
\hline & $\begin{array}{c}\text { за лебединською } \\
\text { породою }\end{array}$ & $\begin{array}{c}\text { за } \\
\text { швіцькою } \\
\text { породою }\end{array}$ & & & \\
\hline Тривалість: життя & $8,0^{* *}$ & $8,8^{* * t}$ & 2,0 & $31,9^{\star \star \star}$ & 0,5 \\
\hline $\begin{array}{l}\text { господарського } \\
\text { використання }\end{array}$ & $9,5^{\star \star \star}$ & $9,9^{\star \star \star}$ & 2,7 & $33,5^{\star \star \star}$ & 0,9 \\
\hline $\begin{array}{l}\text { лактаційного } \\
\text { періоду }\end{array}$ & $9,3^{* * *}$ & $9,4^{\star * *}$ & 3,0 & $30,4^{\star \star \star}$ & $1,7^{*}$ \\
\hline Кількість лактацій & $10,1^{\star \star \star}$ & $10,3^{\star \star \star}$ & 5,1 & $26,7^{\star \star \star}$ & $2,4^{\star \star}$ \\
\hline КГВ & $15,3^{\star \star \star}$ & $15,2^{\star \star \star}$ & 5,8 & $36,9^{\star \star \star}$ & $3,2^{* *}$ \\
\hline Валовий надій & $6,8^{* *}$ & $6,3^{*}$ & 1,8 & $27,2^{\star \star \star}$ & 0,9 \\
\hline $\begin{array}{l}\text { Надій: } \\
\text { за } 1 \text { день життя }\end{array}$ & $8,4^{* *}$ & $7,8^{* *}$ & 4,9 & $27,5^{\star \star \star}$ & $2,9^{* *}$ \\
\hline $\begin{array}{l}\text { за } 1 \text { день } \\
\text { господарського } \\
\text { використання }\end{array}$ & 2,2 & 4,0 & 6,7 & $24,2^{\star \star \star}$ & 0,8 \\
\hline $\begin{array}{l}\text { за } 1 \text { день } \\
\text { лактування }\end{array}$ & 1,5 & 1,7 & 5,3 & $23,4^{\star \star \star}$ & 0,04 \\
\hline
\end{tabular}

${ }^{\star} \mathrm{P}<0,05 ;{ }^{* \star} \mathrm{P}<0,01 ;{ }^{\star \star *} \mathrm{P}<0,001 ;$

Тривалість життя була більшою у тварин 3 умовною кровність за швіцькою породою від 25,1 до $50 \%$. Вони відповідно достовірно переважали тварин з умовною кровністю $75,1-87,5 \%$ (на 16\%, $\mathrm{P}<0,05$ ); $87,6-93,8 \%$ (на $29 \%, \mathrm{P}<0,05$ ); $100 \%$ (на $34 \%$, $\mathrm{P}<0,01)($ табл. 2).

Тварини з умовною кровністю за швіцькою породою в межах 50,1-75,0 достовірно переважали тварин із умовною кровністю $87,6-93,8 \%$ (на $18 \%$, $\mathrm{P}<0,001), \quad 100 \%$ (на $8 \%, \mathrm{P}<0,05)$. Чистопородні лебединські тварини також мали високий показник тривалості життя і за його значенням достовірно переважали висококровних за швіцькою породою тварин: 87,6-93,8\% (на 36\%, Р<0,01), 100\% (на 46\%, $P<0,05)$.

Таблиця 2

Залежність показників довічного використання корів від умовної кровності за швіцькою породою, М士m $(\mathrm{n}=310)$

\begin{tabular}{|l|l|l|l|l|l|l|l|l|}
\hline \multirow{2}{*}{ Показники } & \multicolumn{9}{|c|}{ Yмовна кровність $^{\prime}$} & \multicolumn{1}{|c|}{$0^{1}$} & до 12,5 & $12,6-25,0$ & $25,1-50,0$ & $50,1-75,0$ & $75,1-87,5$ & $87,6-93,8$ & 100 \\
\hline Тривалість: життя & 3388,1 & 2991,2 & 2707,2 & 3526,9 & 3309,3 & 2967,3 & 2498,1 & 2320,8 \\
& $\pm 193,2$ & $\pm 273,8$ & $\pm 326,6$ & $\pm 197,2$ & $\pm 138,3$ & $\pm 136,3$ & $\pm 179,6$ & $\pm 296,9$ \\
\hline господарського & 2438,9 & 2096,6 & 1807,5 & 2560,9 & 2295,9 & 1930,9 & 1443,1 & 1294,2 \\
використання & $\pm 190,7$ & $\pm 273,2$ & $\pm 325,9$ & $\pm 200,7$ & $\pm 139,2$ & $\pm 137,3$ & $\pm 184,0$ & $\pm 269,5$ \\
\hline лактаційного періоду & 2055,8 & 1778,4 & 1552,3 & 2009,1 & 1834,8 & 1551,4 & 1143,2 & 1060,6 \\
& $\pm 142,8$ & $\pm 221,4$ & $\pm 276,9$ & $\pm 165,4$ & $\pm 115,5$ & $\pm 117,1$ & $\pm 152,6$ & $\pm 212,7$ \\
\hline Кількість лактацій & 6,1 & 5,3 & 5,1 & 6,0 & 5,2 & 4,4 & 3,3 & 3,2 \\
& $\pm 0,4$ & $\pm 0,6$ & $\pm 0,9$ & $\pm 0,5$ & $\pm 0,3$ & $\pm 0,3$ & $\pm 0,4$ & $\pm 0,7$ \\
\hline КГВ & 69,3 & 64,7 & 63,3 & 68,3 & 64,3 & 59,3 & 50,4 & 50,6 \\
& $\pm 1,9$ & $\pm 4,1$ & $\pm 4,4$ & $\pm 2,0$ & $\pm 1,7$ & $\pm 1,9$ & $\pm 3,0$ & $\pm 5,5$ \\
\hline Валовий надій & 23756,4 & 21971,9 & 20242,6 & 24139,5 & 22467,6 & 19347,1 & 14230,0 & 13055,6 \\
& $\pm 2131,1$ & $\pm 2737,8$ & $\pm 3795,4$ & $\pm 2224,0$ & $\pm 1562,3$ & $\pm 1014,3$ & $\pm 2171,8$ & $\pm 3171,8$ \\
\hline Надій: & 6,7 & 6,9 & 7,0 & 6,3 & 6,2 & 5,7 & 4,8 & 4,9 \\
за 1 день життя & $\pm 0,3$ & $\pm 0,4$ & $\pm 0,6$ & $\pm 0,3$ & $\pm 0,2$ & $\pm 0,3$ & $\pm 0,4$ & $\pm 0,7$ \\
\hline за 1 день & 9,6 & 11,2 & 11,1 & 9,1 & 9,7 & 9,4 & 9,5 & 9,6 \\
господарського & $\pm 0,3$ & $\pm 0,6$ & $\pm 0,7$ & $\pm 0,4$ & $\pm 0,3$ & $\pm 0,3$ & $\pm 0,6$ & $\pm 0,7$ \\
використання & 11,3 & 12,8 & 12,9 & 11,6 & 12,1 & 11,9 & 12,1 & 11,8 \\
\hline за 1 день лактування & $\pm 0,4$ & $\pm 0,5$ & $\pm 0,8$ & $\pm 0,4$ & $\pm 0,3$ & $\pm 0,3$ & $\pm 0,6$ & $\pm 0,9$ \\
\hline
\end{tabular}

${ }^{1}$ чистопродні тварини лебединської породи

Подібна тенденція характерна і тривалості господарського використання. Тварини із умовною кровністю $50 \%$ за швіцькою породою достовірно переважали тварин з більшою умовною кровністю. 
Тварини лебединської породи достовірно $(\mathrm{P}<0,01$ $0,05)$ переважали висококровних за швіцькою породою тварин

За кількістю лактацій перевагу мають тварин лебединської породи, які достовірно $(\mathrm{P}<0,01-0,05)$ переважали висококровних тварин за швіцькою породою, відповідно: 75,1-87,5 - на 41\%, 87,6-93,8\% - на $87 \%, 100 \%$ - на $89 \%$. Відповідно і тривалість лактаційного періоду була більшою у чистопородних лебединських тварин.

Значення коефіцієнту господарського використання знаходилося в межах 50,4-69,3. Тварини лебединської породи мали найвище його значення і достовірно $(87,6-93,8 \%$ ( $\mathrm{P}<0,001-0,05)$ переважали висококровних за швіцькою породою тварин. Подібна тенденція характерна тваринам 3 умовною кровністю за покращуючою породою 25,6$50 \%$

Основним показником довічної продуктивності $€$ валовий надій молока. За даним показником перевагу мали тварин 3 умовною кровністю за швіцькою породою 25,1-50,0\% $24139,5 \kappa г$, чистопородні лебединські тварини 23756 кг та з умовною кровністю 50,1-75\% - 22467 кг. Тварини 3 меншою умовною кровністю за покращуючою породою також мали середню прижиттєву продуктивність більше 20,0 тис. кг молока. Найменший середній валовий надій спостерігався у тварин з умовною часткою швіцької породи $100 \%$

Найкращими серед усіх груп тварин за показниками тривалості житт, господарського використання та коефіціенту господарського використання виявилися помісні генотипи: групи тварин з умовною кровністю швіцької породи до $50 \%$. За показниками довічного надою і надою за один день життя виявилися тварини з умовною спадковістю швіцької породи від 75,1 до $87,5 \%$.

За надоєм за 1 день життя перевагу мають тварини з умовною кровністю за швіцькою породою $12,6-25,0 \%$. Хоча достовірна різниця встановлена лише з тваринами умовної кровності 87,6-93,8\% - на $45 \%(\mathrm{P}<0,05)$. Достовірно переважали за цим показником висококровних за покращуючою породою тварин чистопородні лебединські тварини $(\mathrm{P}<0,001-0,05)$ та з умовною кровністю до $12,5 \% \quad(P<0,01-0,05)$. Кращим надоєм за 1 день господарського використання та 1 день лактації відрізнялися низькокровні за швіцькою породою тварини - до 12,5 та 12,6-25\%.

Лінійна належність не мала достовірного впливу на показники довічного використання корів.
Найбільшу силу впливу на продуктивне довголіття корів мав фрактор походження за батьком $\left(n^{2} x=23,4-26,9 \%\right)$. Найбільшою тривалістю життя відрізнялися доньки бугаїв-плідників Бігбой 9973

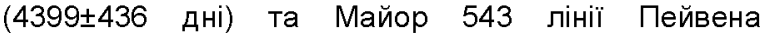
136140 (4350 дні). Менше всього жили доньки бугаяплідника Поліден 3950 лінії Елеганта 148551(1432 дні). Подібна тенденція характерна і показникам тривалості господарського використання та лактаційного періоду. Найбільше раз лактували доньки бугая-плідника Майор 543 - в середньому 8 раз.

Більший середній прижиттєвий надій характерний донькам бугая-плідника Майор 243, який складав 33127 кг. Найменший валовий надій був у доньок бугая-плідника Поліден 3950 - 7059 кг.

На 1 день життя доньки бугая-плідника Фарук 4473 продукували найменшу кількість молока - 3,08 кг, а Майора 543 - найбільшу - 7,5 кг. На один день господарського використання найбільшу кількість молока продукували доньки бугая-плідника Поліден $3950-11,1$ кг, а на один день лактування - Звук $1273-14,7$ кг.

Певний інтерес має вплив породи батька на значення показників тривалості господарського використання. Нами вивчений вплив чистопородних лебединських та швіцьких бугаїв-плідників на досліджувані показники. Встановлено, що за середніми значеннями всіх досліджуваних показників перевагу мали доньки чистопородних лебединських бугаїв-плідників. Причому за кількістю лактацій та лактаційного періоду різниця була достовірною $(\mathrm{P}<0,05)$.

\section{Висновки \\ 1. Встановлений} достовірний високовірогідний вплив генотипових факторів на показники довічного використання корів. Найбільшу силу впливу на продуктивне довголіття корів мав фактор походження за батьком $\left(\eta^{2} x=23,4-26,9 \%\right)$.

2. У Уовна кровність за швіцькою породою достовірно впливала на показники довічного використання тварин. Сила впливу за окремими показниками знаходилась в межах 1,7-15,2\%.

3. Лінійна належність не мала достовірного суттєвого впливу на показники довічного використання тварин.

Перспективи подальиих досліджень. Вважаємо необхідним дослідити залежність показників довічного використання від ступеню інбридингу та варіантів добору.

\section{References}

Buyuklu, H. I., Taranenko, S. V., \& Noskova, A. M. (2013). Tryvalist' hospodars'koho vykorystannya koriv pivdennoho typu ukrayins'koyi chorno-ryaboyi molochnoyi porody. Naukovy yvisnyk «Askaniya-Nova», 6, 103-108. (in Ukrainian).

Polupan, Yu. P. (2014). Efektyvnist' dovichnoho vykorystannya koriv riznykh krayin selektsiyi. Visnyk Sums'koho NAU. Seriya «Tvarynnytstvo», 2/2 (25), 14-20. (in Ukrainian).

Polupan, Yu. P. (2010). Metodyka otsinky selektsiynoyi efektyvnosti dovichnoho vykorystannya koriv molochnykh pored. Metodolohiya naukovykh doslidzhen' z pytan' selektsiyi, henetyky ta biotekhnolohiyi u tvarynnytstvi: materialy naukovo-teoretychnoyi konferentsiyi (Chubyns'ke, 25 lyutoho 2010 roku). Kyiv: Ahrarnanauka, 93-95 (in Ukrainian).

Polupan, Yu. P. (2013). Ontohenetychni ta selektsiyni zakonomirnosti formuvannya hospodars'ky korysnykh oznak molochnoyi khudoby (Dys. doktora sil's'kohospodars'kykh nauk:06.02.01). IRHT UAAN, Chubyns'ke.

Khmel'nychyi, L. M., \& Boyko, Yu. M. (2010). Efektyvnist' dovichnoho vykorystannya koriv riznoyi liniynoyi nalezhnosti ukrayins'koyi buroyi molochnoyi porody. Visnyk Sums'koho NAU. Seriya Tvarynnytstvo, 10(18), 9-12 (in Ukrainian). 
Khmel'nychyy, L. M., \& Vechorka, V. V. (2016). Produktyvne dovholittya dochok buhayiv plidnykiv ukrayins'koyi chornoryaboyi molochnoyi porody. Rozvedennya i henetyka tvaryn, 52, 134-144 (in Ukrainian).

Chechenihina, O. S. (2014). Vliyanie byikov-proizvoditeley na produktivnoe dolgoletie docherey. Agrarnyiy nauchnyiy zhurnal, 11, 42-46 (in Russian).

Sewalem, A., Miglior, F., Kistemaker, G. J., \& Van Doormaal, B. J. (2006). Analysis of the relationship between somatic cell score and functional longevity in Canadian dairy cattle. J. Dairy Sci., 89(9), 3609-3614.

Sewalem, A., Miglior, F., Kistemaker, G. J., Sullivan, P., \& Van Doormaal, B. J. (2008). Relationships between age at first calving and first lactation milk yield, and lifetime productivity and longevity in dairy cows. The Veterinary Record, $162,643-647$.

Haworth, G. M., Tranter, W. P., Chuck, J. N., Cheng, Z., \& Wathes, D. C. (2008). Relationship between reproduction traits and functional longevity in Canadian dairy cattle. J. Dairy Sci., 91, 1660-1668.

Terawaki, Y., \& Ducrocq, V. (2009). Nongenetic effects and genetic parameters for length of productive life of Holstein cows in Hokkaido, Japan. J. Dairy Sci., 92(5), 2144-2150.

\title{
EFFICIENCY OF MIXED BULLS GROWING IN CASE OF CROSSING COWS OF UKRAINIAN RED DAIRY BREED WITH BULLS OF MEAT BREEDS
}

\author{
Y. Chigrinov, O. Kravchuk, N. Syromiatnykova, O. Getmanets \\ Kharkiv State Zooveterinary Academy, Kharkiv, Ukraine \\ Academitchna street, 1, Mala Danilivka, Dergachi district, Kharkiv region, Ukraine, 62341
}

E-mail: E.Chiarinov@ukr.net

Ukrainian breeders evolved and have been evolving meat breeds but at the same time in the nearest future the main part of beef will be produced in dairy cattle- breeding as a by-product of milk production.

The aim of the research was to study the productive and technological qualities of the mixed breeds of cattle produced from crossing of the cows of the Ukrainian Red dairy breed with the bulls of meat breeds: Aberdin Angus, Ukrainian, Volynian and the Southern breed of Znamensky type.

Scientific and production experiment was carried out on the research farm "Stepove" Kirovograd region, at the research agricultural station and 64 bulls of different breed combinations and 16 purebred bulls of Ukrainian Red dairy breed were taken for the experiment.

The bulls under investigation were kept in accordance with the technology and the rules adopted on the farm, they were fed by the same diet. The ration of the bulls was balanced by the detailed standards (Kalashnikov, 1985) that provided the daily weight gains at the level of $900 \mathrm{~g}$ and more. The composition of the feeds was changed depending on the season of the year and the period of animal growing.

The analysis of the change of the live weight of the young cattle kept in the similar technological conditions has shown that the animals of different genotypes had different dynamics of growth. One of the reasons for that was the fact that they had had different live weights at birth. The calves of Aberdin Angus mixed breed had the lowest live weight at birth $(P<0,05)$, due to their high energy of growth they surpassed the animals of the control group in the live weight. They had the highest relative rate of growth from birth to 18month-old age.

The mixed bulls produced from the bull of the Ukrainian Red meat breed had the highest absolute weight gain $(554,5 \mathrm{~kg})$ and, respectively, the highest daily weight gain $(1014 \mathrm{~g})$

The data of the results of the slaughter proved high meat productivity of bulls in all the groups. All groups of mixed bulls had higher slaughtering output by 1,4-3,9\% as compared to the bulls of the control group.

As for the level of profitability of beef production even without donation the bulls produced from crossing the cows of Ukrainian Red dairy breed with the bulls of the Ukrainian meat breed had the best results $(51,3 \%)$, the mixed bulls produced from crossing with Aberdin Angus breed had a little lower values $(50,4 \%)$ than with Volynian meat breed $(47,5 \%)$ and Znamensky type of the Southern meat breed $(46,0 \%)$.

Key words: efficiency of rearing, crossing, mixed bulls, dynamics of growth, profitability

\section{ЕФЕКТИВНІСТЬ ВИРОЩУВАННЯ ПОМІСНИХ БУГАЙЦІВ ВІД СХРЕЩУВАННЯ КОРІВ УКРАЇНСЬКОЇ ЧЕРВОНОЇ МОЛОЧНОЇ ПОРОДИ 3 БУГАЯМИ М'ЯСНИХ ПОРІД}

\author{
Є. І. Чигринов, О. М. Кравчук, Н. А. Сиромятникова, О. М. Гетманець \\ Харківська державна зооветеринарна академія, м. Харків, Україна \\ вул. Академічна, 1, смт. Мала Данилівка, Дергачівський район, Харківська область, 62341 \\ E-mail: E.Chigrinov@ukr.net
}

